\title{
Temperature-Dependent Consolidation of Puromycin-Susceptible Memory in the Goldfish
}

\author{
JOSEPH H. NEALE, PAUL D. KLINGER and BERNARD W. AGRANOFF
}

\author{
Mental Health Research Institute, Neuroscience Laboratory \\ University of Michigan, Ann Arbor 48104
}

\begin{abstract}
Memory of a shock-avoidance task in goldfish (Carassius auratus) maintained at $20^{\circ} \mathrm{C}$ shows a temporal gradient of insusceptibility to post-trial injection of puromycin upon testing 7 days later. Treatment with the antimetabolite $24 \mathrm{hr}$ after training has no effect on retention. There is a significant decrease in the puromycin-induced memory loss if fish are warmed to $30^{\circ} \mathrm{C}$ for a 90 -minute interval between conditioning and injection of puromycin. If fish are cooled to $4.5^{\circ} \mathrm{C}$ for $24 \mathrm{hr}$ between learning and puromycin injection, a significant block of memory results. There are in addition time-independent effects of the cold treatment on performance. Although temperature increase from 20 to $30^{\circ} \mathrm{C}$ does not in itself affect retention, it does cause a 3-fold stimulation of incorporation of ${ }^{3} \mathrm{H}$-leucine into brain protein. Decrease in temperature from 20 to $4.5^{\circ} \mathrm{C}$ reduces protein labeling by $86-97$ percent.
\end{abstract}

\section{INTRODUCTION}

The use of chemical and physical agents to block memory formation has led to the concept of the time-dependency of consolidation of newly acquired behavior into an insusceptible form (McGaugh and Dawson, 1971; Agranoff, 1971). Inhibitors of protein synthesis, such as puromycin (Agranoff and Klinger, 1964) and acetoxycycloheximide (Agranoff, Davis and Brink, 1966), or of RNA synthesis, such as actinomycin D (Agranoff, Davis, Casola and Lim, 1967) and camptothecin (Neale, Klinger and Agranoff, 1973), decrease retention when administered shortly after conditioning of a light-coupled shock-avoidance response in goldfish. These agents are without effect when administered a few hours or days after the initial training session. These observations are consistent with the hypothesis that consolidation of memory requires ongoing protein and RNA synthesis. Since such chemical processes are temperature-dependent and goldfish are poikilotherms, we have examined the effect of temperature on long-term memory formation. Temperature reduction is a potent inhibitor of biochemical and physiological functions (Prosser and Nagai, 1968; Fry, 1971), although cooling in itself has not been reported to be amnestic in poikilotherms. In homeotherms the results are more complex. 
Hamsters cooled to $5^{\circ} \mathrm{C}$ after maze training by immersion in a refrigerated bath were reported to have normal retention upon retesting despite the apparent elimination of electrical activity in the brain shortly after acquisition (Gerard, 1953; Ransmeier and Gerard, 1954). While heartbeat, respiration and brain EEG cease when rats are cooled below $15^{\circ} \mathrm{C}$ (Andjus, Knopfelmacher, Russell and Smith, 1956), Mrosovsky reported that rats made hypothermic shortly after acquisition of a conditioned light-avoidance response showed no significant retention deficit (Mrosovsky, 1963; Mrosovsky, 1967). In contrast, rats cooled to $20^{\circ} \mathrm{C}$ immediately after passive avoidance training had apparent memory losses when tested from 1 to 10 days later (Riccio and Stikes, 1969). Soumireu-Mourat and Cardo recently reported the correlation between cold mediated elimination of spontaneous CNS spike activity and retention loss observed when the cold was administered after partial learning in mice (Soumireu-Mourat and Cardo, 1972). It has alternatively been suggested that the amnesia-like effects of hypothermia in homeotherms may be due to a retrieval failure since increasing the duration of the cold exposure decreases the apparent amnesia (Misanin and Hoover, 1971). In goldfish, multiple exposures to temperature reduction immediately after acquisition trials appear, in one instance, to have facilitated retention (French, 1942). Alternatively, sudden temperature increase, sufficient to produce heat narcosis, is amnestic in goldfish when applied after acquisition, and has been used to demonstrate the time-dependency of consolidation (Cerf and Otis, 1957). Reige and Cherkin have reported that the overall process of acquisition and retention of a single trial avoidance response increases with temperature in goldfish acclimated, conditioned, maintained and tested at 10,20 or $30^{\circ} \mathrm{C}$ (Riege and Cherkin, 1972). While these authors indicated that their observations "could reflect temperature effects upon any point in memory processing, from acquisition through retrieval," the temperature-dependence of memory formation is implied. In trout, temperature reduction to 3 or $1^{\circ} \mathrm{C}$ for $24 \mathrm{hr}$ after acquisition of a conditioned light-shock avoidance response failed to decrease retention despite substantial reduction of incorporation of labeled precursors into protein and RNA (Neale and Gray, 1971; Neale, 1971). Since it also has been reported that a variety of neurophysiological responses are blocked between 6 and $9^{\circ} \mathrm{C}$ in goldfish acclimated to $25^{\circ} \mathrm{C}$ (Peterson and Prosser, 1972) and in rainbow trout cooled to between 1 and $3^{\circ} \mathrm{C}$ (Konishi and Hickman, 1964), it appears that gross disturbance of CNS electrical potentials after acquisition training does not of itself lead to memory loss. Cooling of goldfish to $9^{\circ} \mathrm{C}$ for $2 \mathrm{hr}$ after acquisition does not decrease retention, but it does significantly increase the susceptibility of memory of newly acquired behavior to disruption by electroconvulsive shock (ECS) (Davis, Bright and Agranoff, 1965). We concluded that the rate of consolidation of ECS-susceptible memory was slowed by the temperature decrease. In the present report, we extend a preliminary observation that the rate of 
consolidation of puromycin-susceptible memory also appears to be temperature-dependent (Agranoff, 1972).

\section{METHODS}

Goldfish (Carassius auratus), 6-7 cm long and weighing 8-11 g, obtained from Ozark Fisheries, Stoutland, MO, were maintained under constant illumination, without feeding, in 200-gallon tanks at least 1 wk prior to study. The light-shock avoidance response was conditioned in a shuttlebox (Agranoff et al., 1967) during 30 consecutive acquisition trials at room temperature $\left(20 \pm 1^{\circ} \mathrm{C}\right.$ ) according to a modified version of a procedure described by Bitterman, (1966). Each 60-sec trial consisted of $20 \mathrm{sec}$ of darkness, $20 \mathrm{sec}$ of light presentation (CS) on the side of the box occupied by the fish, followed by $20 \mathrm{sec}$ of light with intermittent shock (US). The trial was terminated by an avoidance or escape response. To avoid the shock, fish swam over a barrier and deflected a transparent swinging gate during the first $20 \mathrm{sec}$ of light. A similar response after the onset of the US was defined as an escape. The CS and US were terminated automatically upon execution of an avoidance or an escape response. Failure to escape was recorded if the fish did not cross the barrier during US presentation. About $20 \%$ of the fish were rejected from further study because they failed to escape more than 9 times or made no avoidances during the 30 acquisition trials, and an additional $10 \%$ were rejected because they made more than 5 correct avoidance responses during the first 10 trials. The number of fish rejected by these criteria varied seasonally, as did performance (Agranoff and Davis, 1968). The present experiments were performed between April and June. Avoidance responses and latencies of escape were detected by photocells and recorded using a PDP-8/S computer which controlled and monitored 10 shuttleboxes simultaneously. The shock frequency was $40 / \mathrm{min}(3.5 \mathrm{~V}$, ac, $0.1 \mathrm{sec}$ duration). Retention was tested by means of a 10-trial session 7 days after acquisition conditioning. Multiple regression analysis based on the number of correct avoidance responses $\left(A_{1}, A_{2}, A_{3}\right)$ and the latency of escape $\left(S_{1}\right.$, $S_{2}, S_{3}$, during trials $1-10,11-20$ and $21-30$, respectively, for untreated control groups was used to determine predicted retention scores for experimental treatment groups according to the formula: predicted score $=K_{0}+K_{1} A_{1}+K_{2} A_{2}+K_{3} A_{3}+K_{4} S_{1}+K_{5} S_{2}+K_{6} S_{3}$, where constants $K_{0}$ through $K_{6}$ were determined from regression analysis of weekly control groups of 20-30 goldfish. Analysis of variance of the mean acquisition scores indicated that there were no significant differences between groups within each experiment. Student's $t$ test for paired data was used to determine the significance of the difference between the achieved and predicted scores (A-P) during retention trials $31-40$. 
Fish were conditioned, maintained and tested at $20 \pm 1^{\circ} \mathrm{C}$ unless otherwise stated. To change temperature after acquisition and during isotopic incorporation studies, fish were placed in plastic tanks identical to their home tanks (Agranoff et al., 1967), which were maintained in a constant temperature bath. Fish maintained at $20^{\circ} \mathrm{C}$ after training were subjected to similar manipulations; i.e., placed in the constant temperature bath at $20^{\circ} \mathrm{C}$ to minimize the potential environmental effects (Davis and Klinger, 1969) of the apparatus on retention.

After various treatments (Tables 2 and 3) fish were injected intracranially (ic) with $130 \mu \mathrm{g}$ of puromycin dihydrochloride (Nutritional Biochemicals, Cleveland, $\mathrm{OH}$ ) in $10 \mu \mathrm{l}$ of saline, and were placed in home tanks.

The effect of temperature change on incorporation of ${ }^{3} \mathrm{H}$-leucine into protein was studied following intraperitoneal (ip) injection of $50 \mu \mathrm{l}$ of a solution containing $10 \mu \mathrm{C}$ of $\left[4,5{ }^{3} \mathrm{H}\right]-\mathrm{L}-$ leucine (sp act, $46.9 \mathrm{Ci} / \mathrm{mmole}$, Amersham). Just prior to use, the labeled precursor was taken to dryness to remove ${ }^{3} \mathrm{HOH}$ produced by decomposition. The radioactivity in the residue gave a single chromatographic spot which migrated with unlabeled leucine carrier. The radioactive amino acid was injected $30 \mathrm{~min}$ after fish were placed at $4.5^{\circ} \mathrm{C}$, or $60 \mathrm{~min}$ after fish were placed at 10,20 , or $30^{\circ} \mathrm{C}$. Fish were killed 10 or $30 \mathrm{~min}$ after injection, and pools of 5 brains were homogenized in $5 \mathrm{ml}$ of water. Aliquots $(0.2 \mathrm{ml})$ of the homogenates were dried on filter paper discs, and the protein was precipitated in the paper by the addition of $10 \%$ trichloroacetic acid (TCA) (Mans and Novelli, 1961). Samples were taken to dryness to remove ${ }^{3} \mathrm{HOH}$ (Lim and Agranoff, 1969; Banker and Cotman, 1971). Nonvolatile radioactivity in the TCA supernatant fraction was counted to determine the amount of unincorporated labeled amino acid in the brains. Over $70 \%$ of this radioactivity has been shown to be in leucine $30 \mathrm{~min}$ after injection at $20^{\circ} \mathrm{C}$ ( $\mathrm{Lim}$ and Agranoff, 1969). The radioactive protein was washed in $5 \% \mathrm{TCA}$ at $80^{\circ} \mathrm{C}, 95 \%$ ethanol, $100 \%$ ethanol and two times with ether before oxidation to ${ }^{3} \mathrm{HOH}$ and collection in a Packard sample oxidizer. The low incorporation values observed at $4.5^{\circ} \mathrm{C}$ served as a control to indicate that under the conditions of extraction, little TCA-soluble radioactivity was adsorbed to the precipitate. The amounts of radioactivity in the protein samples in the nonvolatile, acid-soluble fraction were determined in a Packard 3375 liquid scintillation spectrometer at $36 \%$ efficiency and corrected to disintegrations per minute $(\mathrm{dpm})$ using an external standard. The rate of ${ }^{3} \mathrm{H}$-leucine incorporation into protein was estimated from the ratio of the radioactivity in the protein precipitate to that in the TCA supernatant ( $\mathrm{Lim}$ and Agranoff, 1969). 


\section{RESULTS AND DISCUSSION}

\section{Incorporation of Labeled Amino Acid into Protein}

Protein synthesis was estimated in goldfish brains during a $30 \mathrm{~min}$ incorporation interval following intraperitoneal injection of ${ }^{3} \mathrm{H}$-leucine at 4.5 , 10 and $20^{\circ} \mathrm{C}$ (Expt A, Table 1) or during a $10 \mathrm{~min}$ incorporation interval at 20 and $30^{\circ} \mathrm{C}$ (Expt B, Table 1). At $20^{\circ} \mathrm{C}$, the amount of labeled amino acid in the brain increases linearly with time for up to $30 \mathrm{~min}$ ( $\mathrm{Lim}$ and Agranoff, 1969 ). For $30^{\circ} \mathrm{C}$, we used a 10 -min interval, since preliminary experiments

TABLE 1

Effect of Temperature on Incorporation of $\left[{ }^{3} \mathrm{H}\right]$ Leucine into Goldfish Brain Protein ${ }^{a}$

\begin{tabular}{|c|c|c|c|c|c|}
\hline & $\begin{array}{l}\text { Temp } \\
\left({ }^{\circ} \mathrm{C}\right)\end{array}$ & $\begin{array}{l}\text { Acid-precipitable }(P) \\
\left(\mathrm{dpm} \times 10^{-3} / \text { brain }\right.\end{array}$ & $\begin{array}{l}\text { Acid-soluble }(S) \\
\left(\text { dpm } \times 10^{-3} /\right. \\
\text { brain })\end{array}$ & Ratio $P / S$ & $\begin{array}{c}\text { Change relative } \\
\text { to } 20^{\circ}(\%)\end{array}$ \\
\hline \multirow[t]{4}{*}{ Expt A } & \multicolumn{5}{|c|}{$30 \mathrm{~min}$ isotopic incorporation interval } \\
\hline & 20.0 & $\begin{array}{l}18.7 \\
23.2 \\
26.3\end{array}$ & $\begin{array}{l}130 \\
147 \\
137\end{array}$ & $\begin{array}{r}.1440 \\
.1586 \\
.1921 \\
\text { Mean } .1649\end{array}$ & \\
\hline & 4.5 & $\begin{array}{l}1.508 \\
0.454 \\
0.195\end{array}$ & $\begin{array}{l}67.3 \\
67.6 \\
47.5\end{array}$ & $\begin{array}{l}.0224 \\
.0067 \\
.0041\end{array}$ & $\begin{array}{l}-86 \\
-96 \\
-97\end{array}$ \\
\hline & 10 & $\begin{array}{l}2.85 \\
6.04 \\
3.29\end{array}$ & $\begin{array}{r}88.5 \\
111.6 \\
86.1\end{array}$ & $\begin{array}{l}.0323 \\
.0541 \\
.0382\end{array}$ & $\begin{array}{l}-80 \\
-67 \\
-77\end{array}$ \\
\hline \multirow[t]{3}{*}{ Expt B } & \multicolumn{5}{|c|}{10 min incorporation interval } \\
\hline & 20.0 & $\begin{array}{l}0.922 \\
1.145 \\
0.894 \\
0.754\end{array}$ & $\begin{array}{l}28.9 \\
30.5 \\
27.3 \\
22.3\end{array}$ & $\begin{array}{r}.0319 \\
.0376 \\
.0328 \\
.0338\end{array}$ & \\
\hline & 30 & $\begin{array}{l}4.93 \\
5.40 \\
6.16 \\
5.52\end{array}$ & $\begin{array}{l}37.0 \\
50.4 \\
53.0 \\
48.5\end{array}$ & $\begin{array}{r}\text { Mean } .0340 \\
.1331 \\
.1072 \\
.1162 \\
.1139\end{array}$ & $\begin{array}{l}+392 \\
+315 \\
+342 \\
+335\end{array}$ \\
\hline
\end{tabular}

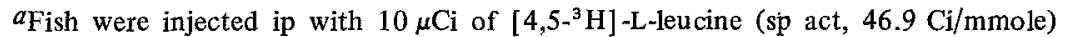
$30 \mathrm{~min}$ after being transferred to $4.5^{\circ} \mathrm{C}$ or $60 \mathrm{~min}$ after being transferred to 10,20 or $30^{\circ} \mathrm{C}$ constant temperature tanks from room temperature holding tanks. In Expt A, brains were removed $30 \mathrm{~min}$ after injection while in Expt B brains were removed $10 \mathrm{~min}$ after injection. The radioactivity incorporated into protein (acid-precipitable) and the unincorporated nonvolatile radioactivity (acid-soluble) in pools of 5 brains were determined. 


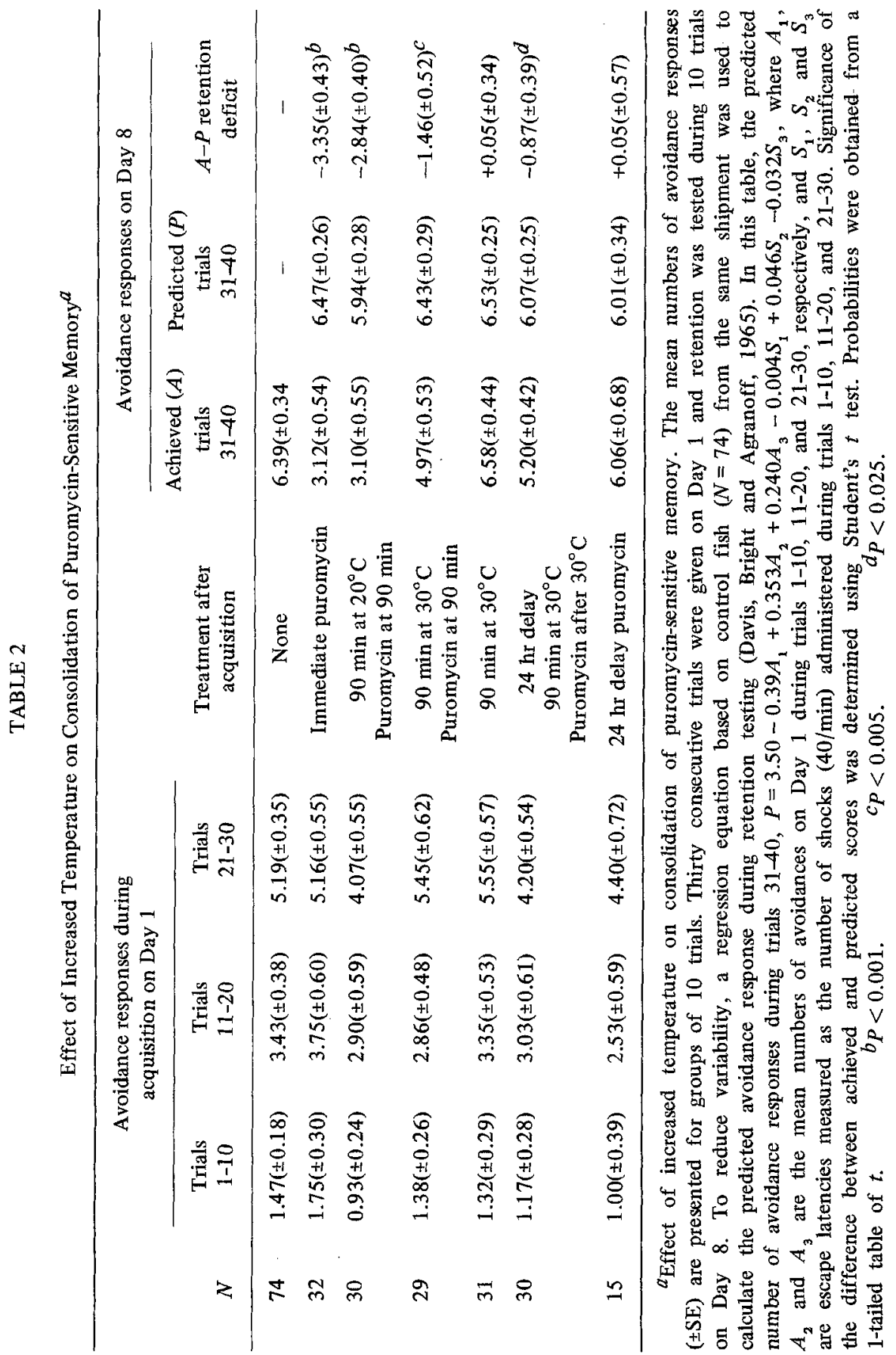




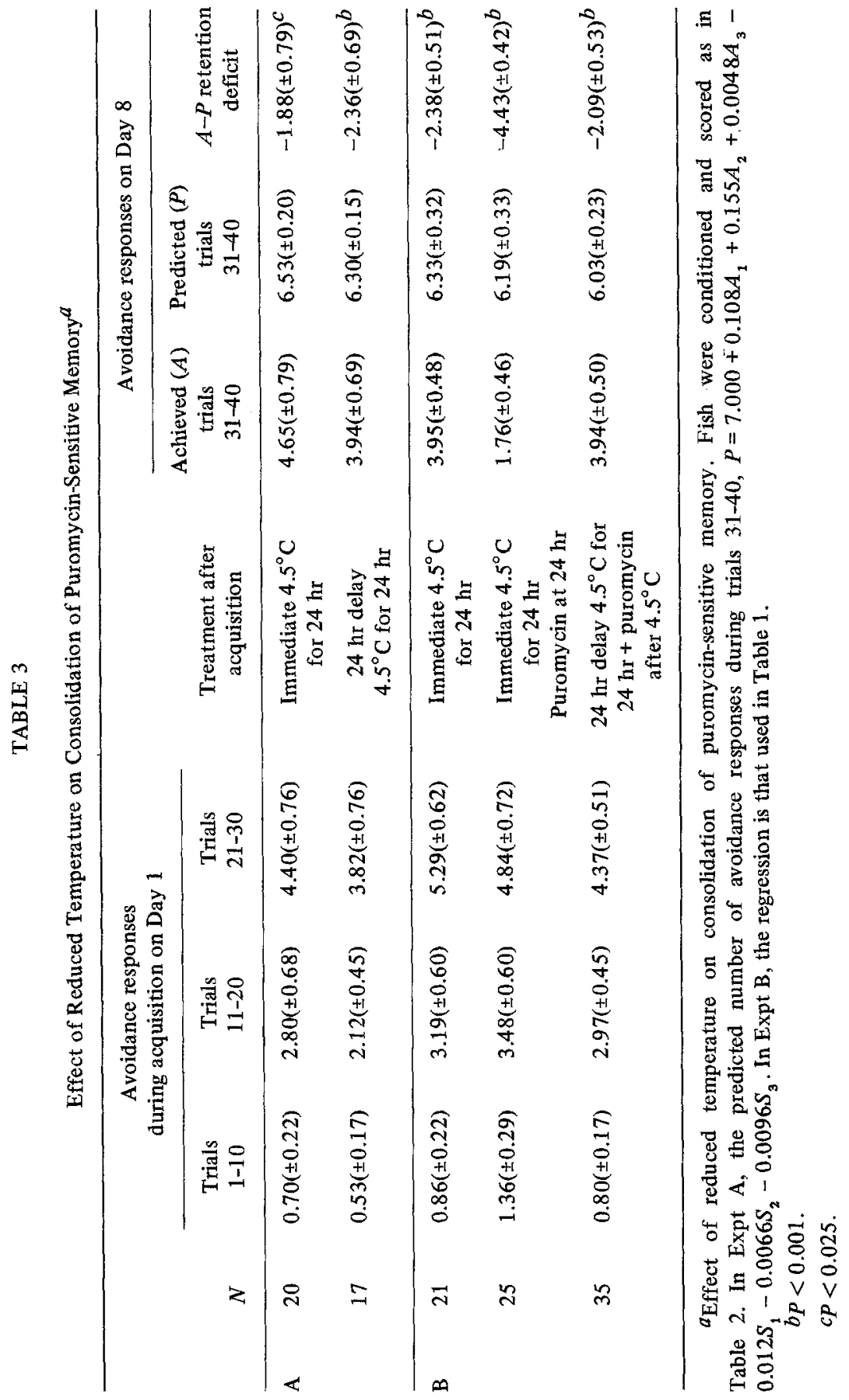


indicated a loss of linearity between 20 and $30 \mathrm{~min}$. At $4.5^{\circ} \mathrm{C},{ }^{3} \mathrm{H}$-leucine incorporation into protein decreased by $86-97 \%$ compared with the value at $20^{\circ} \mathrm{C}$. In other experiments in which the labeled amino acid was injected at various intervals after fish were placed at $4.5^{\circ} \mathrm{C}$, the low level of labeling observed after $30 \mathrm{~min}$ in the cold was found to persist throughout the $24 \mathrm{hr}$ tested. Temperature reduction to $10^{\circ} \mathrm{C}$ reduced incorporation of ${ }^{3} \mathrm{H}$-leucine into protein by $67-80 \%$, while a temperature increase to $30^{\circ} \mathrm{C}$ accelerated incorporation by $315-392 \%$ (Expt B, Table 1). These results confirm previous findings (Neale and Gray, 1971; Das and Prosser, 1967) that temperature significantly affects the rate of protein synthesis in the teleost brain.

\section{Increased Temperature and Retention}

Increasing temperature following acquisition training had no effect on retention, but consolidation of the conditioned response was accelerated (Table 2). As we had shown previously, puromycin injected ic immediately after acquisition reduced retention of the response $(\mathrm{A}-\mathrm{P}=-3.35, P<0.001)$. The same treatment delayed $24 \mathrm{hr}$ after acquisition had no effect, while an intermediate deficit $(\mathrm{A}-\mathrm{P}=-2.84, P<0.001)$ was also observed when puromycin was injected $90 \mathrm{~min}$ after trial 30 , indicating that some puromycin-susceptible memory remained at that time. However, memory in fish maintained at $30^{\circ} \mathrm{C}$ for a similar 90-min interval after acquisition was much less susceptible to puromycin. Fish subjected to $30^{\circ} \mathrm{C}$ for $90 \mathrm{~min}$ postacquisition showed no deficit on Day 8 . The deficit in the $30^{\circ} \mathrm{C}+$ puromycin group $(A-P=-1.46, P<0.005)$ was significantly less than that observed at $20^{\circ} \mathrm{C}(-2.84$ vs $-1.46, P<0.01)$. When the combined treatments of $90 \mathrm{~min}$ at $30^{\circ} \mathrm{C}$ and subsequent puromycin were delayed until $24 \mathrm{hr}$ after acquisition, a small deficit was observed $(A-P=-0.87, P<0.025)$. Since memory formation appears to be complete well before the $24 \mathrm{hr}$ delayed treatment, this deficit is considered to be a reflection of residual sickness effects on performance during retesting. However, this performancerelated deficit observed in the $24 \mathrm{hr}$ delay group may also account for some of the deficit observed in the group exposed to $30^{\circ} \mathrm{C}$ immediately after acquisition with puromycin $90 \mathrm{~min}$ later. If so, temperature increase enhances consolidation even more than we have indicated. The retention deficit produced by puromycin after $90 \mathrm{~min}$ at $30^{\circ} \mathrm{C}$ could thus be as small as -0.59 . The result that increasing temperature to $30^{\circ} \mathrm{C}$ for 90 min immediately after acquisition alone did not affect retention supports the finding that for train-test intervals from $15 \mathrm{~min}$ to $17 \mathrm{hr}$, retention is independent of temperature (Riege and Cherkin, 1972). The major conclusion of this experiment is that the temperature elevations appear to have increased the rate of consolidation of puromycin-susceptible memory; within $90 \mathrm{~min}$, this process is nearly complete at $30^{\circ} \mathrm{C}$, while long-term memory formation is still susceptible to puromycin in fish maintained at $20^{\circ} \mathrm{C}$. 


\section{Decreased Temperature and Retention}

Fish subjected to $4.5^{\circ} \mathrm{C}$ for $24 \mathrm{hr}$ either immediately after training or after a $24 \mathrm{hr}$ delay (Expt A, Table 3) had significant retention deficits of similar magnitudes. This lack of a temporal gradient suggested that the effect of cooling was not related to memory formation or retention, and was possibly a result of residual sickness from the treatment itself. In a related study (Expt B, Table 3), posttraining exposure to $4.5^{\circ} \mathrm{C}$ for $24 \mathrm{hr}$ again produced a deficit. However, fish injected with puromycin after $24 \mathrm{hr}$ posttraining temperature reduction had a deficit significantly larger than that produced by cooling alone $(A-P=-4.43$ vs $-2.38, P<0.01)$. The deficit was also larger than that observed following delayed treatment with cooling + puromycin $(A-P=-4.43$ vs $-2.09, P<0.01)$. Taken together, these experiments indicate that in addition to a time-independent effect of the treatment on performance, temperature reduction to $4.5^{\circ} \mathrm{C}$ for $24 \mathrm{hr}$ also delayed the development of puromycin insusceptibility. In another experiment, similar in design to those in Table 3 , cooling to $4.5^{\circ} \mathrm{C}$ for $24 \mathrm{hr}$ produced no retention deficit $(A-P=0.22, N=30)$. This variation in effects of temperature reduction alone on performance may correlate with seasonal changes in the resistance of goldfish to temperature reduction (Fry, 1971).

In an attempt to reduce the apparent nonspecific effect of cooling on performance, we studied extensively $(N=448)$ the effects of $10^{\circ} \mathrm{C}$, applied for $3 \mathrm{hr}$ after acquisition, on the rate of development of puromycin-susceptibility. A substantial $(A-P=-3.44, \pm 0.43 \mathrm{SE})$ deficit was observed in fish maintained at $10^{\circ} \mathrm{C}$ for $3 \mathrm{hr}$ after acquisition, then injected with puromycin and returned to room temperature. A smaller but significant deficit $(A-P=-1.15$, $\pm 0.54 \mathrm{SE}$ ) was observed when the cooling + puromycin treatment was delayed $24 \mathrm{hr}$. When fish were maintained at room temperature for $3 \mathrm{hr}$ prior to puromycin injection, it appeared that consolidation was not complete at $20^{\circ} \mathrm{C}$ $(A-P=-1.59, \pm 0.50 \mathrm{SE})$. Since these two effects could be additive in the group kept at $10^{\circ} \mathrm{C}$ for $3 \mathrm{hr}$ immediately after acquisition and followed by puromycin, the effect of cooling to $10^{\circ} \mathrm{C}$ on consolidation cannot be resolved. In previous studies, using slightly different conditioning procedures, neither $3 \mathrm{hr}$ at $14^{\circ} \mathrm{C}$ (Agranoff, 1972) nor $2 \mathrm{hr}$ at $9^{\circ} \mathrm{C}$ had significant effects on performance or retention. The differences between these studies and the results presented here may be due to seasonal variation in thermal tolerance. The use of a somewhat higher temperature $\left(12^{\circ}-15^{\circ} \mathrm{C}\right)$ may prove more useful in cooling experiments with goldfish acclimated to $20^{\circ} \mathrm{C}$.

The absence of a time-dependent effect of cooling on retention supports previous findings that severe temperature reduction shortly after learning is not amnestic in trout (Neale, 1971). Since cooling disrupts CNS electrical potentials in fish (Konishi and Hickman, 1964; Peterson and Prosser, 1972), these results support the proposal that short-term memory does not depend upon "reverberating circuits or any other purely dynamic process" (Gerard, 1953). 
In summary, experiments with cooling were more difficult to interpret than the $30^{\circ} \mathrm{C}$ studies because of apparent effects of temperature reduction alone on subsequent performance. We conlcude, nevertheless, that cooling does retard memory formation. Although the response to temperature reduction may be variable, in each experiment in which puromycin was given after cooling, a deficit resulted that was dependent on the time after learning that cooling was initiated, and the net effect of temperature reduction was to prolong the susceptibility to puromycin. With cooling alone, there was no indication of a time-dependency of the effect.

This study indicates that neither temperature reduction to $4.5^{\circ} \mathrm{C}$ nor temperature increase to $30^{\circ} \mathrm{C}$ immediately after acquisition is, in itself, amnestic. The temperature during the interval between acquisition and puromycin injection exerts a potent influence on the rate of memory formation, since it can increase or decrease the interval following acquisition during which puromycin is effective in disrupting retention. These results confirm our findings that cooling extends the period during which memory is susceptible to another amnestic treatment, ECS (Davis, Bright and Agranoff, 1965). The possibility that the reinforcing or aversive aspects of temperature change account for any of these effects is unlikely, since both raising and lowering temperature abruptly are sufficiently aversive to motivate behavioral thermoregulation (Rozin, 1968), whereas in the present study warming and cooling have opposite effects on memory formation.

These experiments are of further interest in that protein synthesis, per $s e$, is dissociated from memory formation. Temperature reduction to $4.5^{\circ} \mathrm{C}$ immediately after acquisition consistently produced no greater retention deficit than a similar treatment $24 \mathrm{hr}$ after learning. This failure to produce a temporal amnestic gradient, while profoundly inhibiting macromolecular synthesis for periods up to $24 \mathrm{hr}$, is in contrast to the reduced synthesis and decreased retention observed upon administration of antimetabolites. An important difference between temperature- and chemically mediated inhibition of protein synthesis is that in the former, brain metabolism is depressed while in the latter, protein synthesis is inhibited selectively. Production of an amnestic effect by protein synthesis inhibitors may require ongoing turnover of brain protein in the absence of synthesis.

\section{REFERENCES}

Agranoff, B. W. (1971). Effects of antibiotics on long-term memory formation in goldfish. In W. K. Honig and P. H. R. James (Eds.), "Animal Memory," pp. 243-258. New York: Academic Press.

Agranoff, B. W. (1972). Further studies on memory formation in the goldfish. In J. L. McGaugh (Ed.), "The Chemistry of Mood, Motivation, and Memory," Advances in Behavioral Biology, Vol. 4, pp. 175-185. New York: Plenum. 
Agranoff, B. W., and Davis, R. E. (1968). The use of fishes in studies on memory formation. In D. Ingle (Ed.), "The Central Nervous System and Fish Behavior," pp. 193-201. Chicago: University of Chicago Press.

Agranoff, B. W., Davis, R. E., and Brink. J. J. (1966). Chemical studies on memory fixation in goldfish. Brain Res. 1, 303-309.

Agranoff, B. W., Davis, R. E., Casola, L., and Lim, R. (1967). Actinomycin D blocks formation of memory of shock-avoidance in goldfish. Science 158, 1600-1601.

Agranoff, B. W., and Klinger, P. D. (1964). Puromycin effect on memory fixation in the goldfish. Science 146, 952-953.

Andjus, R. K., Kopfelmacher, F., Russell, R. W., and Smith, A. U. (1956). Some effects of severe hypothermia on learning and retention. Quart. J. Exp. Psychol. 8, 15-23.

Banker, G., and Cotman, C. W. (1971). Characteristics of different amino acids as protein precursors in mouse brain: advantages of certain carboxyl-labeled amino acids. Arch. Biochem. Biophys. 142, 565-573.

Bitterman, M. E, (1966). Animal learning. In J. B. Sidowski (Ed.), "Experimental Methods and Instrumentation in Psychology," pp. 451-484. New York: McGraw-Hill.

Cerf, J. A., and Otis, L. S. (1957). Heat narcosis and its effect on retention of a learned behavior in the goldfish. Fed. Proc., Fed. Amer. Soc. Exp. Biol. 16, 20-21. (Abstr.).

Das, A. B. and Prosser, C. L. (1967). Biochemical changes in tissues of goldfish acclimated to high and low temperatures. I. Protein synthesis. Comp. Biochem. Physiol: 21, 449-467.

Davis, R. E., Bright, P. J., and Agranoff, B. W. (1965). Effect of ECS and puromycin on memory in fish. J. Comp. Physiol. Psychol. 60, 162-166.

Davis, R. E., and Klinger, P. D. (1969). Environmental control of amnestic effects of various agents in goldfish. Physiol. Behav. 4, 269-271.

French, J. W. (1942). The effect of temperature on the retention of maze habit in fish. $J$. Exp. Psychol. 31, 79-87.

Fry, F. E. J. (1971). The effect of environmental factors on the physiology of fish. In W. E. Hoar and D. J. Randall (Eds.), "Fish Physiology," Vol. 6, pp. 1-98. New York: Academic Press.

Gerard, R. W. (1953). What is memory? Sci. Amer. 189, 118-126.

Konishi, J., and Hickman, C. P. (1964). Temperature acclimation in the central nervous system of rainbow trout, Salmo gairdnerii. Comp. Biochem. Physiol. 13, 433-442.

Lim, R., and Agranoff, B. W. (1969). Protein metabolism in goldfish brain. $J$. Neurochem. 16, 431-445.

Mans, R. J., and Novelli, G. D. (1961). Measurement of the incorporation of radioactive amino acids into protein by a filter-paper disc method. Arch. Biochem. Biophys. 94, 48-53.

McGaugh, J. L., and Dawson, R. G. (1971). Modification of memory storage processes. In W. K. Honig and P. H. R. James (Eds.), "Animal Memory," pp. 215-242. New York: Academic Press.

Misanin, J. R., and Hoover, M. (1971). Recovery rate as a determinant of the amnesic-like effect of hypothermia. Physiol. Behav. 6, 689-693.

Mrosovsky, N. (1963). Retention and reversal of conditioned avoidance following severe hypothermia. J. Comp. Physiol. Psychol. 56, 811-813.

Mrosoviky, N. (1967). Lowered body temperature, learning and behavior. In K. C. Fisher, A. R. Dawe, C. P. Lyman, E. Schonbaum and F. E. South Eds.), "Mammalian Hibernation III," pp. 152-174. London: Oliver and Boyd.

Neale, J. H. (1971). Protein synthesis, ribonucleic acid synthesis, and retention of a conditioned response in rainbow trout as affected by temperature reduction. $\mathrm{PhD}$ dissertation, Georgetown University, Washington, D.C. 
Neale, J. H., and Gray, I. (1971). Protein synthesis and retention of a conditioned response in rainbow trout as affected by temperature reduction. Brain Res. 26, 159-168.

Neale, J. H., Klinger, P. D., and Agranoff, B. W. (1973). Camptothecin blocks memory of conditioned avoidance in goldfish. Science 179, 1243-1246.

Peterson, R. H., and Prosser, C. L. (1972). The effects of cooling on electrical responses of goldfish (Carassius auratus) central nervous system. Comp. Biochem. Physiol. 42A, 1019-1037.

Prosser, C. L., and Nagai, T. (1968). Effects of low temperature on conditioning in goldfish. In D. Ingle (Ed.), "The Central Nervous System and Fish Behavior," pp. 171-180. Chicago: University of Chicago Press.

Ransmeier, R. E, and Gerard, R. W. (1954). Effects of temperature, convulsion and metabolic factors on rodent memory and EEG. Amer. J. Physiol. 179, 663-664. (Abstr).

Riccio, D. C., and Stikes, E. R. (1969). Persistent but modifiable retrograde amnesia produced by hypothermia. Physiol. Behav. 4, 649-652.

Riege, W. H. and Cherkin, A. (1972). One-trial learning in goldfish: temperature dependence. Behav. Biol. 7, 255-263.

Rozin, P. (1968). The use of poikilothermy in the analy sis of behavior. In D. Ingle (Ed.), "The Central Nervous System and Fish Behavior," pp. 181-192. Chicago: University of Chicago Press.

Soumireu-Mourat, B., and Cardo, B. (1972). Hypothermia profonde chez la souris: perturbations de l'activité electrique centrale et d'un apprentissage d'approache. Physiol. Behav. 9, 183-190. 